\title{
"A STUDY TO ASSESS THE EFFECTIVENESS OF STRUCTURED TEACHING PROGRAMME REGARDING KNOWLEDGE ON MANAGEMENT OF COLD CHAIN SYSTEM OF VACCINES AMONG ANMS IN SELECTED CHC SANGANER, JAIPUR." Doula Ram Nursing Officer AIIMS,Raipur \\ Corresponding Email: doularambhkr44@gmail.com
}

\section{ABSTRACT}

Introduction: Vaccine is an immune-biological- substance designed to produce specific protection against a given disease. It stimulates the production of protective antibody and other immune mechanisms. "Cold chain maintenance" is the system of storage and transport of vaccines at a low temperature from the manufacturer to the actual vaccine site.

Material \& Methods: The research approach adopted for the study was pre-experimental research approach. The research design adopted for the study was experimental research design. The data was collected through the tool which is prepared by the investigator. The sample consists of the 50 ANMs. The tool used for the data collection was structured knowledge questionnaire, which has three sections.

Result: The paired' test value was 11.42 and it was significant at P 0.001 level. This revealed that the STP had improved the knowledge.

Conclusion: The overall pretest mean knowledge score of respondents found to be 13.68 percent and SD as 5.94 percent among the respondents on cold chain maintenance.

Keyword: Assess, effectiveness, structured teaching programme cold chain

Introduction: Assess the changes which occurred in the cold chain status after the intervention undertaken to improve the status and also to assess the awareness of the cold chain handlers regarding cold chain maintenance. Intervention consisted of reorganization of cold chain points and training of health manpower in Kolkata Municipal area regarding immunization and cold chain following the guidelines as laid by Govt. of India. ${ }^{1}$

this study was conducted to evaluate the availability and functioning of cold chain equipment as well as knowledge. It was a cross-sectional study involving a multistage sampling. 3 urban and 5rural districts were selected randomly from the 19 health districts of the North West region. In each district all the health facilities taking part in the EPI were targeted. Data were collected using a questionnaire administered face to face to health personnel and with an observational grid to assess availability, functioning, and monitoring of cold chain equipment and power supply. The data were analyzed using the EPI-info software. ${ }^{2}$

A descriptive cross-sectional study design was employed in this study. The 
study population consisted of registered nurses, auxiliary nurses and community health extension workers in primary health care facilities in Benin City, Edo State. The tool for data collection was pre-tested, structured self-administered questionnaire. Bivariate analysis between sociodemographic variables and practice of cold chain management was done. Binary logistic regression was also done to determine significant predictors of practice of cold chain management. The level of significance was set at $\mathrm{p}<0.05$ for all associations. A total of 425 respondents participated in this study. Over two-thirds of respondents 314 (73.9\%) had good practice of cold chain management. Significant determinants of practice of cold chain management were cold chain management training $(p=0.004)$, presence of functional refrigerators $(\mathrm{p}=$ $0.016)$, NPI supervision $(\mathrm{p}<0.001)$ and higher level of education $(\mathrm{p}<0.001)$. The practice of cold chain management among respondents was fair. ${ }^{3}$

According to Lugosi and Batters by, studies in developed and developing countries have shown that many vaccines are stored inadequately and that the vaccine cold chain can be disrupted. ${ }^{4}$

A study conducted on Knowledge and practice of oral polio vaccine (OPV)- vaccine vial monitor (VVM) among health personnel in India, presented that, health workers carried OPV vials in their pockets. $13 \%$ of respondents among a total of 115 health personnel endorsed the decision of health workers who carried OPV vials in their pockets and administered the vaccine as long as the VVM (Vaccine Vial Monitor) has not changed its color. ${ }^{5}$

\section{Objectives:}

To assess the knowledge of ANMs regarding cold chain maintenance before and after administering structured teaching programme.

To evaluate the effectiveness of structured teaching programme by comparing the pre test and post test knowledge scores regarding the management of cold chain system vaccine among ANMs.

To identify the association between the pre test knowledge scores of ANMs with the selected socio demographic variables.

\section{Methodology:}

The research approach: adopted for the study was pre-experimental research approach.

The research design: adopted for the study was experimental research design.

Setting of the study: The study was conducted inCHCs, PHCs, and Sub centers 
in Sanganer, Jaipur (Rajasthan) the rural area included.

Sample and sampling technique: The sample of this study the samples were 50 ANMs who are working in rural areas, CHCs, PHCs, and sub centre

Data Collection: The tool used for the data collection was structured knowledge questionnaire, which has three sections:

Section $\boldsymbol{A}$-This section consists of information about the demographic data of ANMs such as Age, Academic qualification, working place, Total professional experience, in service training on cold chain system.

Section B-This section consists of structured knowledge questionnaire on 30 items. Each item is multiple choices in nature with 4 responses in each question. There was one correct response that carries one mark and the wrong response carries zero mark. The total score was 30 for 30

Section $\boldsymbol{C}$ - Structured teaching programme was developed based on review of literature and the objectives stated for knowledge test. The title of the structured teaching was

Collected data analyzed by using descriptive and inferential statistics in terms of frequency, percentage, mean, standard deviation, Chi - square test.
Analysis of the pre test knowledge of ANMs regarding management of cold chain system vaccines.

Table: 1. Frequency and percentage distribution of Pre-test knowledge of ANMs regarding management of cold chain system vaccines.

$\mathbf{N}=\mathbf{5 0}$

\begin{tabular}{|l|l|l|l|l|}
\hline $\begin{array}{l}\text { Knowledge } \\
\text { score }\end{array}$ & Frequency & Percentage & Mean & S.D \\
\hline $1-10$ & 23 & 46 & & \\
\hline $11-20$ & 17 & 34 & \multirow{2}{*}{5.68} & \\
\hline $21-30$ & 10 & 20 & & \\
\hline
\end{tabular}

1. Data in table 1 reveals that $23(46 \%)$ of the ANMs had poor knowledge \& $17(34 \%)$ of them had moderate knowledge and 10(20\%) of them had adequate knowledge on management of cold chain system of vaccines.

2. Some ANMs have adequate knowledge regarding management of cold chain system of vaccines.

Table: 2. Frequency and percentage distribution of Post-test knowledge of ANMs regarding management of cold chain system vaccines.

$\mathbf{N}=\mathbf{5 0}$

\section{RESULTS:}




\begin{tabular}{|l|l|l|l|l|}
\hline $\begin{array}{l}\text { Knowled } \\
\text { ge score }\end{array}$ & $\begin{array}{l}\text { Freque } \\
\text { ncy }\end{array}$ & $\begin{array}{l}\text { Percent } \\
\text { age }\end{array}$ & Mean & S.D \\
\hline $1-10$ & 6 & $12 \%$ & & \\
\hline $11-20$ & 27 & $54 \%$ & 18.42 & 4.90 \\
\hline $21-30$ & 17 & $34 \%$ & & \\
\hline
\end{tabular}

Data in table 2 reveals that most of them (34\%) of the ANMs had adequate knowledge \& 54\% of them had moderate knowledge ANMs regarding Management of Cold Chain System Vaccines. in the post test. It shows that the structured teaching programme was highly effective regarding knowledge on selected management of cold chain system vaccines. The overall post-test knowledge mean score found to be 18.42 and SD 4.90.

Table: 3 Mean, Mean Difference, Standard Deviation, and ' $t$ ' Value of Pretest and Post-test knowledge score of ANMs.

$\mathbf{N}=\mathbf{5 0}$

$\mathrm{T}_{49}=2.015, \mathrm{p}<0.05$

\section{* Significant}

Data in table 3 shows that the mean post-test knowledge score (18.42) was higher than the mean pre-test knowledge score (13.68). The computed't' value $\left(\mathrm{t}_{49}=11.42\right)$ was higher than the table value $\left(t_{49}=2.015\right)$ at 0.05 level of significance.

\begin{tabular}{|c|c|c|c|c|c|c|}
\hline \multirow{2}{*}{ Group } & \multicolumn{2}{|c|}{$\begin{array}{l}\text { Mean } \\
\text { knowledge } \\
\text { score }\end{array}$} & \multirow{2}{*}{$\begin{array}{l}\text { Mean } \\
\text { difference }\end{array}$} & \multicolumn{2}{|c|}{$\begin{array}{l}\text { Standard } \\
\text { deviation }\end{array}$} & \multirow{2}{*}{$\begin{array}{l}\text { t } \\
\text { value }\end{array}$} \\
\hline & $\begin{array}{l}\text { Pre- } \\
\text { test }\end{array}$ & $\begin{array}{l}\text { Post- } \\
\text { test }\end{array}$ & & $\begin{array}{l}\text { Pre- } \\
\text { test }\end{array}$ & $\begin{array}{l}\text { Post- } \\
\text { test }\end{array}$ & \\
\hline ANMs & 13.68 & 18.42 & 4.74 & 5.94 & 4.90 & 11.42 \\
\hline
\end{tabular}

Hence the research hypothesis $\mathbf{H}_{1}$ is accepted and it was inferred that the mean difference between pre- and post-test knowledge score was statistically significant.

Analysis of the pre test and post test knowledge of ANMs regarding management of cold chain system of vaccines.

Table 4: Distribution of ANMs according to the grading of pre-test and post-test knowledge score.

$$
\mathbf{N}=\mathbf{5 0}
$$

\begin{tabular}{|c|c|c|c|c|}
\hline \multirow[b]{2}{*}{ Grading } & \multicolumn{2}{|l|}{ Pre-test } & \multicolumn{2}{|l|}{ Post-test } \\
\hline & $\begin{array}{l}\text { Frequency } \\
\text { (f) }\end{array}$ & $\begin{array}{l}\text { Percentage } \\
(\%)\end{array}$ & $\begin{array}{l}\text { Frequency } \\
\text { (f) }\end{array}$ & $\begin{array}{l}\text { Percenta } \\
\text { ge }(\%)\end{array}$ \\
\hline Poor & 23 & $46 \%$ & 6 & $12 \%$ \\
\hline Moderate & 17 & $34 \%$ & 27 & $54 \%$ \\
\hline Good & 10 & $20 \%$ & 17 & $34 \%$ \\
\hline
\end{tabular}


Table: 6. Association of demographic variables and Pre test knowledge of ANMs regarding Management of Cold Chain System of Vaccines.

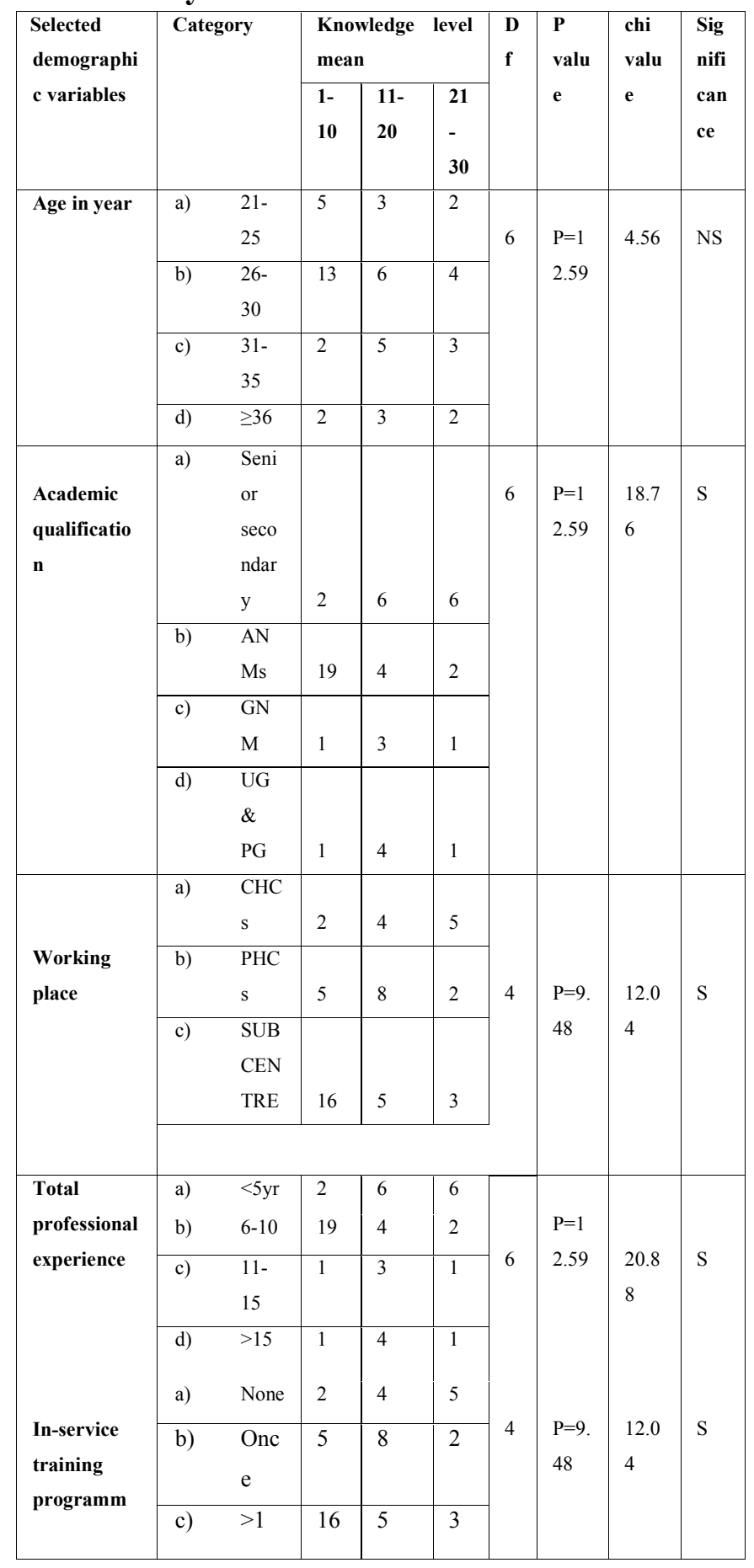

Interpretation and conclusion: The overall pretest mean knowledge score of respondents found to be 13.68 percent and SD as 5.94 percent among the respondents on cold chain maintenance. Further the overall posttest mean score of respondents are 18.42 percent and SD 4.90 percent among the respondents on cold chain maintenance.

\section{References:}

01. Kaipilyawar SB, Laxminarayan J. Andhra Pradesh cold chain system marching beyond routine to obtain $\mathrm{WHO}$ accreditation. Indian $\mathrm{J}$ Public Health 2004; 48(2 (April-June):57-9.

02. Immunisation handbook 2002. Wellington Ministry of Health; 2002.

03. Keshav swarnkar, community health nursing, 2007, page no. 126.

04. Galazka A, Milstien J, Zaffran M. Thermostability of vaccines. Geneva: Global Programme the effects of freezing on the appearance, potency, and toxicity of adsorbed and unadsorbed DPT vaccines. Weekly Epidemiological Record, 55; 1980, pp. 385-90.

05. Baswanthappa B.T.Nursing research, Jaypee Publication, $2^{\text {nd }}$ edition (2007) Page No. 23-40. 